\title{
The effect of stock prices, return on assets, and firm size on dividend payout ratio: evidence from Indonesian financial service companies
}

\author{
Mira Septiani' ${ }^{1}$, Nafiah Ariyani ${ }^{1}$, and Heri Ispriyahadi² \\ ${ }^{1}$ Post Graduate of Sahid Jakarta University, Indonesia \\ ${ }^{2}$ STIE Muhammadiyah Jakarta, Indonesia
}

\begin{tabular}{ll}
\hline Abstract & This paper aims to investigate the effect of stock prices, return on assets (ROA), and firms \\
size on dividend payout ratio (DPR). We used 5-year annualized panel data from 2014 to \\
2018 of 17 financial sector companies listed in the Indonesian Stock of Exchange (IDX) as \\
sample of this study. Analysis using three regression estimations (pooled OLS, fixed effects, \\
and random effects) showed that stock price positively affects DPR. On the other hand, \\
both ROA and firm size has a negative effect on DPR. These result suggests that more \\
substantial and higher profit companies prefer to retain their earnings for financing an \\
investment as a growth opportunity than to distribute their income as a dividend. Thereby, \\
this agrees with the pecking order theory.
\end{tabular}

Keywords

stock price; return on assets (ROA); firm size; dividend payout ratio (DPR)

\section{INTRODUCTION}

Scientific review on issues related to dividends distributed by a corporation have received considerable attention among scholars and managers. For this reason, the company's payout policy still becomes an exciting topic to study. Dividends payment is matters because investors or potential investors use it to monitor the company's performance and the prospects of a company. Likewise, dividends have an essential role in the company's capital structure (Eviani, 2015; Rehman, 2016; Paminto et al., 2016). A company must establish an appropriate dividend policy because it usually affects the value of a company (Jiang et al., 2017). However, if the company paid out dividends, there are consequences that firms will face difficulties to preserve sufficient funds in financing its growth in the future, and the company's shares would become unattractive. Therefore, companies must cope with to determine the right proportion between retention ratio and dividend payout ratio (DPR).

According to $\mathrm{He}$ et al. (2017), dividend distribution policy is one of the functions in financial management decisions besides investment and corporate funding decisions. The dividend policy regulates the portion of net income that will be distributed to shareholders following the number of shares they owned and the remaining net income retained by the corporation for reinvestment. Yusof \& Ismail (2016) stated that companies can distribute dividends to their shareholders in two different forms: cash payment (i.e., cash dividend) or in additional shares of stock (i.e., stock dividend). The amount of dividend payment between companies is varied depending on their respective dividend policies (Kadir, 2010). Some companies that can generate substantial profits but have limited investment opportunities, generally distribute most of their wealth to the shareholders. Conversely, companies that are still at the growth phase and unable to produce substantial profits usually would prefer to distribute dividends in smaller amounts. The dividend payment is significant for the company because it can reflect the profitability the company has achieved (Henry \& Koski, 2017).

The corporation dividend payout policy is still a subject of debate because there are many different judgments. Some people argue that dividends should be paid as much as possible because they assume that the stock price is influenced by how much the dividends are paid. Some people also believe that the dividend should be distributed at the least possible amount due to the presence of a threshold fee and a high 
dividend tax rate. Accordingly, they think it would be better to retain the net income to reduce the cost. Finally, some argue that the dividend should be paid after several investments have been taken because there might be other investment opportunities with higher returns to satisfy the investors (Labhane \& Das, 2015; Elmagrhi et al., 2017)

According to Giel et al. (2019), the purpose of investors to invest their funds is to earn returns on investment. Dividend income or capital gain is a form of proceeding obtained from the investment. For investors, the distribution of dividends in cash is more desirable than other types. A cash dividend is claimed to help investors reduce uncertainty in their investment activities in the company. Cash dividends may not transfer substantial income to investors; however, investors assume that it is unlikely that in the next payment period, the management can record profits and distribute dividends in cash to shareholders (Kaźmierska-Jóźwiak, 2015).

Meanwhile, from the managers' viewpoint, distributing cash dividends is going to reduce the company's cash assets possession (Mui \& Mustapha, 2016). Management will limit cash outflows arising from cash dividend payments if it deems necessary for the survival of the company (e.g., to invest and pay off corporate debts). Accordingly, the managers will always have a careful review of their company's dividend policy because it involves various interests of related parties.

In practice, if a company that pays dividend decide to diminish its dividend payments, shareholders often will tend to overreact. Dividends might cause such a reaction implicitly passed the information to shareholders; that is, the increase and decrease in dividend payments reflect the improvement or deterioration in the company's prospects (Marpaung \& Hadianto, 2009). Thus, analysts and investors who will buy securities in the capital market often have an initial examination of the company's financial statements that could be done by studying the size of stock prices, the amount of return on assets (ROA), company size, and others. In this study, the researchers had selected certain factors that are considered to have a substantial influence on dividend distribution policy. Those include stock prices, ROA, and company size. These three variables are widely used in previous studies to find out the effect on dividend policy on companies (Syaiful, 2016; Amalia, 2017; Apriliani,2017; Atmoko 2017Enow and Hugh, 2018). A detailed explanation of the influential factors mentioned earlier will be embedded in the following paragraphs.

The share price is the price of a company's shares in the stock market at a specific time settled by market participants as well as by the demand and supply of the relevant shares in the capital market. The higher the stock price of a company, the more likely it is that investors or shareholders will get more enormous dividends. Such a condition happens due to the amount of dividend paid, and the number of shares outstanding will always look for conformity. The management will set a higher DPR than they did in the past to encourage shareholders to invest in their shares, which could eventually boost the company's future shares price (Kadir, 2010). Against previous statements, the researchers presumed that stock price is having an influence on the size of the dividend to be distributed by a company.

$R O A$ is another factor thought to be affecting the company's dividend distribution policy. This factor is measured by calculating the profitability ratio that indicates the percentage of profits (net income) acquired by the company concerning total resources or the average amount of assets. Otherwise, ROA is a ratio that calculates the company's efficiency in handling its assets to create profits over a period. ROA assists managers and investors to see how well a company can convert its investment in assets into benefits. ROA is generally considered as a return on investment for a firm due to capital assets are often made up of the most substantial portion in investment funds. The higher the level of ROA obtained by a firm, the higher the performance of a firm, and so does the chance of getting dividends; vice versa (Trang et al., 2015).

The last factor that is considered to impact the dividend distribution scheme of a company in this study is the firm's size, which is proxied by total assets. The total assets of a company used in research typically being transformed into natural logarithms unit to simplify its immense value. Company size could affect the number of dividends to be paid because the turnover and profits generated shall get higher when the company is growing larger. If the 
company manages to obtain considerable benefits, it can raise the company's capability to make dividend payments (Rais \& Santoso, 2017).

In Indonesia's context, most research on the DPR was carried out on manufacturing companies such as among others research by (Kadir, 2010; Samrotun, 2015; Lestari et al., 2017). To the author's best knowledge, few researchers examined an extensive study on DPR in financial services sector companies. The company's financial services sector was chosen as a research object because these companies have yet to become the main engine for economic growth in Indonesia. This industry contributes by providing financing to various parties for several purposes. Besides, different characteristics from other sectors, the financial services firms fairly fascinating to study. This study will provide an empirical investigation of factors that influence dividend distribution policy in Indonesia's financial services sector companies.

\section{LITERATURE REVIEW AND HYPOTHESES DEVELOPMENT}

\section{Literature review}

Dividends in general are profits for limited liability corporations. The total amount a company pays in dividends usually determined in a GMS, which is stated in a certain amount or percentage of nominal shares rather than market value. The DPR is generally referred to as the DPR. This financial ratio is used to measure the percentage of net income distributed to shareholders in dividends during specific periods (generally within one year). Hence, the DPR is a standard variable used to assess the companies dividend payout policy of which calculation formula is as follows (Wahyuni and Hafiz 2018):

$$
\text { Dividend Pay Out Ratio }=\frac{\text { Dividend Per Share }}{\text { Earning Per Share }}
$$

According to Rais \& Santoso (2017), there are several existing theories related to dividend policy. First is irrelevant dividend theory. According to Miller \& Modigliani (1961), the value of a company is not determined by the size of the DPR but rather by net income before taxes and the company's risk class. Based on this theory, dividend policy does not affect the stock price or the cost of capital of a company. They also argued that the value of a company is only specified by the essential ability to generate profits and business risks.

Second is the bird in the hand theory. As stated by Linter (1956) and Gordon (1963), when the dividend payout is low, the costs of the company's capital will increase. This is because investors prefer dividends over capital gains. This theory also holds that investors favor dividends because cash in hand is more valuable than wealth in other forms. Consequently, the company's share price will be driven by how much dividends are paid. An increase in dividends will increase the share prices, which ultimately affect the value of a company.

Third is theory of tax differences. Dividend policy theory, according to Litzenberger and Ramaswamy (1982), dividends and capital gains are subject to tax. However, investors frequently prefer capital gains over dividends because they can delay the tax payments. If the tax on dividends is higher than the tax on capital gains, this difference will be more evident.

Fourth is theory of signaling hypothesis. There is empirical evidence that shows that if there is an increase in dividends, it will be accompanied by an increase in share prices, vice versa. It is another reason why investors prefer dividends over capital gains. The theory also states that investors will see changes in dividends as a signal of earning forecast given by the management. A rise in dividends that is often followed by an increase in share prices has long been observed, where the dividend cuts will usually lead to a decrease in stock prices.

Fifth is clientele effect theory. This theory reported that shareholders have a different perspective on a company's dividend policy. A high DPR is preferred by investors who need immediate income. In contrast, the investors who do not require an immediate cash payment will prefer the company to withhold most of its net profit. If a company holds back and reinvests profits instead of paying dividends, shareholders in an urgent financial situation will be at a disadvantage. On the other hand, shareholders who choose not to received dividends will get more benefits. These investors will be taxed at a lower rate and save more time from doing a fund reinvestment after they received a tax refund.

Stocks are defined as securities that represent the ownership portion of a 
company. Shares are usually marketed in the capital market, where people who own or provide funds with those who need funds are being facilitated by trading securities that have the maturity of more than one year. Market value is the price at which securities are quoted in the stock market at a particular time and calculated by the market actors. The stock price in this study is the market price of stocks in the sufficient closing period or closing price on December 31 of each research year, with indicators using Ln (natural logarithm) of the stock price.

ROA according to Idawati \& Wahyudi (2015) is a ratio that shows how much the contribution of assets in deriving the net income. This ratio is used to measure how much net income will be generated from each rupiah of funds embedded in total assets. The higher the ROA indicator achieved by a company, the higher the net profit could be generated from each rupiah of funds embedded in total assets. Conversely, the lower the ROA ratio may result in the lower net profit earned by a company from each rupiah of money embedded in total assets. The formula used to calculate ROA is as follows (Sartono 2015):

$$
\text { Return on Assets }(\mathrm{ROA})=\frac{\text { Net Profit }}{\text { Total Asset }}
$$

In line with Rais \& Santoso (2017), firm size is defined as the measurement to classify the size of the company according to various calculations. They are based on total assets, total sales, average total sales of assets, log size market value shares, number of employees, and others. The size of a company could be an indicator that illustrates the level of risk for investors to invest in the company. Large firms are deemed to have an excellent financial capacity, more capable of fulfilling all of their obligations, and can accommodate an adequate return rate for investors. The computation that commonly used to gauge the firm size is as follows:

$$
\text { Firm Size }=\text { Log Natural Total Assets }
$$

\section{Hypotheses development}

The financial service companies in Indonesia are examined and explored in terms of the impact of stock prices, ROA, and firm size, on their DPR. The hypotheses of this study are:

\section{H1: The stock price has a positive effect on the DPR of financial services companies in Indonesia.}

For investors, dividends serve as a popular source of investment income. For the issuing company, they are a way to redistribute profits to shareholders to thank them for their support and to encourage additional investment. Dividends also serve as an announcement of the company's success. Therefore, there is a relationship between stock prices and dividend distribution policies.

When the stock price rises, the management will consider a higher DPR. This is supported by previous research (Wonggo et al. 2016) states stock prices have a significant effect on cash dividends, both partial and simultaneous.

H2: ROA has a positive effect on the DPR of financial services companies in Indonesia.

High profitability shows good company prospects so that investors will react positively to these signals indicating the increase of firm value. This is understandable because the company that managed to record increased profits demonstrates that it has an excellent performance that generates a positive sentiment for investors.

ROA reflects the efficiency of management in managing company assets to generate profits. The higher ROA owned by the company, the dividend to be also paid higher because the stock issuer makes a substantial profit; it tends to pay more in the form of dividends and vice versa. This is confirmed by research (Zais 2016 and Apriliani et al. 2017), which states ROA has a positive and significant effect on dividend policy.

H3: firm size has a positive effect on the DPR of financial services companies in Indonesia.

Firm size represents the company capability to maximize firm profitability and dividend payment (Arifin, 2007). Firms with large size will have a significant opportunity 
Table 1.

Population Characteristics and Number of Research Samples

\begin{tabular}{|c|c|}
\hline Information & Total \\
\hline $\begin{array}{l}\text { Financial s service sector companies cegistered on the Indonesia stock exchange } \\
\text { (IDX) 2014-2018 }\end{array}$ & 79 \\
\hline \multicolumn{2}{|l|}{ Ineligible financial services sector s companies: } \\
\hline $\begin{array}{l}\text { 1. Financial service sector companies that do not settle dividends during the } \\
\text { research period. }\end{array}$ & 48 \\
\hline $\begin{array}{l}\text { 2. Financial service sector companies that do not have the complete data } \\
\text { needed for research. }\end{array}$ & 14 \\
\hline Sub-total ineligible companies & 62 \\
\hline Total sample (eligible companies) & 17 \\
\hline Total data used ( 5 years observation) & 85 Data \\
\hline
\end{tabular}

Note. Reproduced from www.idx.co.id, www.sahamok.com, and www.yahoofinance.com, 2019.

Table 2.

List of Research Samples

\begin{tabular}{lll}
\hline No. & Sample Code & \multicolumn{1}{c}{ Issuer's Name } \\
\hline 1 & ABDA & Asuransi Bina Dana Arta Tbk \\
2 & ADMF & Adira Dinamika Multifinance Tbk \\
3 & ASBI & Asuransi Bintang Tbk \\
4 & ASRM & Asuransi Ramayana Tbk \\
5 & BBCA & Bank Central Asia Tbk \\
6 & BBMD & Bank Mestika Dharma Tbk \\
7 & BBNI & Bank Negara Indonesia (Persero) Tbk \\
8 & BBRI & Bank Rakyat Indonesia (Persero) Tbk \\
9 & BBTN & Bank Tabungan Negara (Persero) Tbk \\
10 & BFIN & BFI Finance Indonesia Tbk \\
11 & BJBR & Bank Jabar Banten Tbk \\
12 & BJTM & Bank Pembangunan Daerah Jawa Timur Tbk \\
13 & BMRI & Bank Mandiri (Persero) Tbk \\
14 & MFIN & Mandala Multifinance Tbk \\
15 & MREI & Maskapai Reasuransi Indonesia Tbk \\
16 & PANS & Panin Sekuritas Tbk \\
17 & PEGE & Panca Global Securities Tbk \\
\hline & &
\end{tabular}

Note. Researcher processed data, 2019.

to pay a higher dividend than the small one. The size of a large company usually determines the number of dividends to be paid. Because the more significant the company, the sales and profits generated, and if the benefit obtained high, the dividends to be distributed are substantial and vice versa.

Some empirical analyses show that firm size has a positive relationship with the

\section{Population and sample}

The population in this study are all financial service companies that are listed on the Indonesia Stock Exchange from 2014 to 2018 (5 years), with a total of 79 companies. These companies are grouped into banks (43 companies), financial services (15 companies), securities (7 companies), and insurance (14 companies). 
Table 3.

Results of the chow test analysis

\begin{tabular}{crrr}
\hline Test cross-section fixed effects & & & \\
\hline Effect Test & Statistic & d.f. & Prob. \\
\hline Cross-Section F & 10.386 .029 & $(16,65)$ & 0,0000 \\
Cross-Section Chi-Square & 107.847 .495 & 16 & 0,0000 \\
\hline
\end{tabular}

Table 4.

Hausman test result

\begin{tabular}{cccc}
\hline \multicolumn{4}{c}{ Test cross-section Random effects } \\
\hline Test Summary & Chi-Sq Statistic & Chi-Sq d.f. & Prob. \\
\hline Cross-Section Random & 8.152673 & 3 & 0,0430 \\
\hline
\end{tabular}

Table 5.

Multicollinearity test result

\begin{tabular}{cccc}
\hline \multicolumn{4}{c}{ Correlation } \\
\hline & Stock Price & ROA & Firm Size \\
\hline Stock Price & 1.000 .000 & -0.140353 & 0.537061 \\
ROA & -0.140353 & 1.000 .000 & -0.554265 \\
Firm Size & 0.537061 & 0.554265 & 1.000 .000 \\
\hline
\end{tabular}

The sampling technique exercised in this study is purposive sampling according to specific criteria. Those criteria used are as follow (1) financial service companies that are registered on the Indonesia Stock Exchange and Provide financial report during the study period, from 2014 to 2018 ; (2) financial services that are punctual in submitting their audited version of financial statements and registered regularly; and (3) the company has all the necessary data required in this research, such as stock price data, and companies that distribute dividends throughout the research period and others.

In summary, the population and sample of this investigative study that satisfied the prerequisite criteria are presented in the Table 1. Based on the sample selection criteria, a list of companies examined in this study is showed in the Table 2.

The panel data regression model is a regression analysis that attempted to observe data obtained over multiple periods. This statistical method is generally estimating the parameters in cross-sectional data using the least squares estimation approach known as Ordinary Least Square (OLS). Panel data is a mix of time-series data (dataset recorded over a specific period) and cross-sectional (data collected at one time), meaning that the data does not contain multiple time elements, and groups of respondents classify the data itself). The advantage of using panel data regression is that there are times when researchers are unable to conduct an analysis using only time-series data or cross-section data (Doğan, 2013).

The classical assumption test was conducted after obtaining the best method or approach from panel data. According to Sinaga (2018), in panel data regression, classical assumption tests that exist in the OLS method do not necessarily must be taken, yet multicollinearity and heteroscedasticity tests are still fundamental.

Hypothesis testing was carried out to determine the results of the partial significance test (t-test) and the F-test of overall significance (Torres-Reyna, 2014).

\section{RESULTS AND DISCUSSION}

\section{Panel data testing}

To get the best panel data regression model, the chow-test and Hausman-test were performed so that the method chosen would match the data characteristics and research 


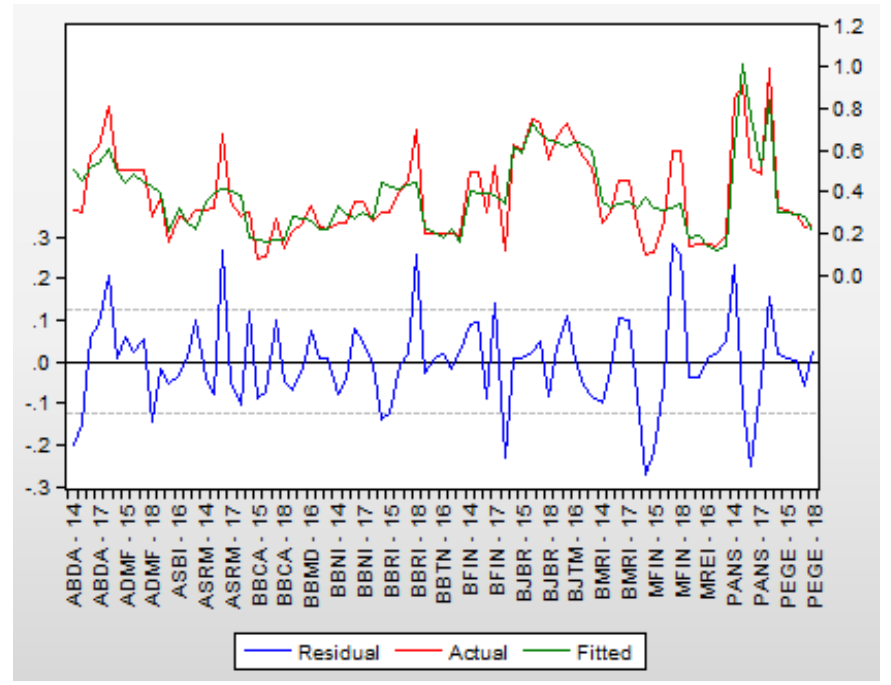

Figure 1.

Heteroscedasticity test result

objectives. These tests also conducted to determine which regression model that the one of effect model (CEM), fixed effect model (FEM), or random effect model (REM) could give more accurate estimation results (Torres-Reyna, 2014).

Chow-test is a statistical test to choose the best model between the common effect model (CEM) and the fixed-effect model (FEM). The result of this test is displayed in the Table 3.

The econometric test was performed using the E-views program with a confidence level of $95 \%(\alpha=5 \%)$. According to the figure above, the chi-square critical value is 0.0000 , which is less than $\alpha(0.05)$. Thus, the ideal estimation method to be employed is the fixed effect model (FEM).

After conducting the chow test, a Hausman test was then exercised to determine the best regression model amidst the fixed-effect model (FEM) or the random effect model (REM). The results of the Hausman test are shown in Table 4.

From the results Table 4, the Hausman test was performed employing the E-views program with a confidence level of $95 \%(\alpha=$ $5 \%$ ). The random cross-section value is 0.0430 , where the value is less than $\alpha(0.05)$. Accordingly, the best estimation method to be utilized is the fixed effect model (FEM). Testing classic assumptions. This classic assumption test aims to find out whether the data that have been collected are feasible for further investigation. Thus, the classic assumption tests exercised in this study are as follows:

A multicollinearity test was conducted to measure the intercorrelations between independent variables (Cahyono \& Prabawa, 2011). A regression model ideally should not present any correlation between independent variables. The multicollinearity problem can be found by analyzing the correlation value between tested variables. If the correlation value among variables is more significant than 0.8 , in that case, it can be concluded that there is a multicollinearity problem in the model. Table 5 disclosed the statistical results of multicollinearity tests that had been carried out by the researchers.

From the table above, it can be concluded that the correlation value across independent variables used in this study falls below 0.8 . It is, therefore, the dataset that is free from multicollinearity problems.

The heteroscedasticity test is a statistical examination to identify the presence of variance in residual for all observations in the linear regression model. A good regression model should present homoscedastic variance in its random variables.

The figure shown above is a chart used to observe whether there is a heteroscedasticity problem in the specification employed. Based on the generated outcome, it can be seen that each residual forms an uncertain graphical pattern and tends to be constant. Therefore, it can 
Table 6.

Partial regression test results (t-test)

\begin{tabular}{ccccc}
\hline Variable & Coefficient & Std Error & t-statistic & Prob. \\
\hline C & 2.729521 & 1.106521 & 2.466760 & $0.0163^{* * *}$ \\
STOCK PRICE & 0.101352 & 0.047603 & 2.129096 & $0.0370^{* * *}$ \\
ROA & -2.397644 & 0.739854 & -3.240700 & $0.0019^{* * *}$ \\
FIRM SIZE & -0.178614 & 0.071561 & -2.495965 & $0.0151^{* * *}$ \\
\hline
\end{tabular}

Notes. ${ }^{*},{ }^{* *},{ }^{* *}$ : indicate significant level at $10 \%, 5 \%$ and $1 \%$

Table 7.

Overall significance test results (F-test)

\begin{tabular}{lcll}
\hline Root MSE & 0.109378 & R-Squared & 0.719834 \\
Meand Dependent var & 0.381100 & Adjusted R- Squared & 0.637940 \\
S.D. dependent var & 0.207870 & S.E. of regression & 0.125078 \\
Akaike info criterion & -1.117427 & Sum squared resid & 1.016900 \\
Schwarz criterion & -0.542686 & Log Likehood & 67.49066 \\
Hannah-Quinn Criter & -0.886250 & F- statistic & 8.789759 \\
Durbin-Watson stat & 1.491235 & Prob(F-Statistic) & 0.000000 \\
\hline
\end{tabular}

be concluded that the research data is free from the heteroskedasticity problem.

\section{Hypotheses testing}

After performing several statistical tests with E-views 11 software, the fixed-effect model (FEM) is the best regression model to be applied in this study. Results that were successfully gathered from the relevant regression test directly answer all the hypotheses in this study. The following are further discussions of the results of the tests.

The statistical effect each independent variable has on the dependent variable was carried out by employing a partial significance test (t-test). From the results captured in the table 6 , it can be observed that all independent variables affetc the dependent variable.

From the results shown, it can be seen that the stock price has a positive coefficient of 0.1013 with a probability value of 0.0370 . The result also indicates that the $p$-value $0.0370<\alpha 0.05$. Therefore, $\mathrm{H} 1$ is supported, implying that the stock price has a significant influence on the DPR.

As displayed in Table 6, it can be observed that the ROA has a negative coefficient of 2.33976 with a probability value of 0.0019 . This indicates that the $p$ value $0.0019<\alpha 0.05$, therefore $\mathrm{H} 2$ is not supported.

It can also be seen in Table 6 that firm size has a negative coefficient of 0.1786 with a probability value of 0.0151 . This shows that the $p$-value $0.0151<\alpha 0.05$ and that $\mathrm{H} 3$ is not supprted.

According to the regression test result, the outcome suggests that the F-test value of 8.7897 and statistically significant with a probability value of $0.0000<\alpha=0.05$. Thus, it can be judged that stock prices, ROA, and company size altogether has a significant effect on DPR.

As displayed in Table 7, the result of $\mathrm{R}$ squared is 0.719834 . It means that all independent variables, which are stock price, ROA, and firm size provide $71.98 \%$ influences simultaneously towards the DPR. The rest of $28.02 \%$ is influenced by other variables that are not examined in this study.

\section{Discussion}

As shown in the regression test results above, the DPR of Indonesian financial service companies that are registered on the Indonesia Stock Exchange is affected by the stock prices, ROA, and company size.

\section{Effect of stock prices on DPR}

The finding indicates that the stock price has a positive effect on DPR. Our finding in line with hypothesis ( $\mathrm{H} 1)$. Accordingly, it is confirmed that stock price fluctuation is affecting the amount of dividends to be paid by the financial service companies in Indonesia. This research outcome is 
following empirical studies conducted by Wonggo, et al. (2016) and Zais (2017), which discovered that stock prices affect dividends. They explained that the amount of dividends shared to investors and the number of stocks issued by a corporation will always seek compatibility. When a company wants its share prices to be increased in the next period, the managers will set out a higher DPRto raise investors' incentive to buy the company's shares (Anwar, 2016). Based on our empirical evidence, the result supports the argument of Signaling Theory, which stated that investors prefer dividends income over capital gains. A rise in stock prices shall lead to a higher amount of dividends to be paid out to shareholders, and vice versa. Besides, this finding also in line with the research outcome obtained by Rais et al. (2017), which suggests a definite causal relationship between stock prices and dividends payment.

\section{Effect of ROA on DPR}

A regression test result between ROA and dividends payment shows a negative coefficient that is significant at a $5 \%$ level. Our finding suggested that our hypothesis $(\mathrm{H} 2)$ is not supported. Accordingly, the higher the ROA value, the better it is for a company to use internal equity to finance an investment as a growth opportunity. Our finding on this variable conforms with the Pecking Order Theory on capital structure. Thus, large companies prefer to retain their earnings than to distribute their income as dividends. The negative impact of ROA on Dividend Payments also can be found in Wonggo, et al (2016) and Wicaksono, et al (2016) investigative study.

\section{Effect of firm size on the DPR}

Our study confirmed that firm size has a negative effect on DPR, meaning that our hypothesis (H3) is also not supported. Our finding suggested that the larger the company, the higher the investment opportunity that the company will have. With so many investment opportunities, it would be better if the existing income is invested in the investment opportunity to produce a positive NPV so that the company has less obligation to pay dividends. This reasoning is following the theory of residual dividends, which states that the company sets a dividend distribution policy after all profitable investments are being financed. Our finding research rejected hypothesis $(\mathrm{H} 3)$. However, our finding on this variable is also in line with the research outcome generated by Apriliani et al. (2017) and Atmoko et al. (2017), which shows that company size affects dividend policy.

\section{CONCLUSION}

The purpose of this research is to figure out the impact of stock price, ROA, and company size on DPR of financial sector service companies. In light of this study it concludes that all these factors are a significant impact on dividend policy. The stock price has a positive and considerable influence on the DPR of financial sector service companies. A rise in stock prices will lead to a higher amount of dividends paid out to shareholders. In contrast, both ROA and firm size has a negative sign. This study claims that the larger the company, the higher the investment opportunity that the company will have. It would be better if the current income is invested in the investment opportunity that can produce a positive NPV so that the company has less obligation to pay dividends. Thus, large companies prefer to retain their earnings than to distribute their income as dividends. Overall, our empirical study found that the determinants of dividend policy decisions in Indonesian financial institutions are similar to those of nonfinancial institutions, which have been documented previously in the existing literature.

The results of this study provide useful information for investors and corporations. For investors, they are advised to invest their funds in the companies that can generate maximum profits. Even so, factors like stock prices, ROA, and company size should also be considered, w corporates management asare suggested to make the best effort to achieve excellent financial performance so that these companies can attract investors to invest their wealth in thescompanies' stocks. Of course, this research was hindered by several limitations. The first limitation of this research is related to the data coverage. The data used in this study is limited to financial service companies listed on the Indonesia Stock Exchange, so the results cannot be applied in all industrial sectors. A second limitation is the study only uses three independent variables of research consist of prices, ROA, and firm size. Finally, there is 
also a limitation period examined in this study only from 2014 -2018. For future research, we recommend including other lists of industries that are excluded in this study as the research object and add more variables that are thought to influence the DPR.

\section{REFERENCES}

Ahmad, G. N., \& Wardani, V. K. (2014). The effect of fundamental factor to dividend policy: Evidence in Indonesia Stock Exchange. International Journal of Business and Commerce, 4(2), 14-25

Anwar, Syaiful., (2016). Pengaruh Laba Bersih, Harga Saham, Profitabilitas, Leverage, Serta Arus Kas Operasi Terhadap Dividen Tunai (Studi Empiris Pada Perusahaan Manufaktur yang Terdaftar Pada Bursa Efek Indonesia Periode 2010 - 2014), Universitas Dian Nuswantoro.

Apriliani, Amalia., dan Natalylova, Kartina., (2017).Faktor-Faktor yang Mempengaruhi Kebijakan Dividen Pada Perusahaan Manufaktur Di Bursa Efek Indonesia, STIE Trisakti, Jurnal Bisnis dan Akuntansi ISSN: 1410 - 9875 Vol. 19 , No. 1A, November 2017, Issue 1, 4957.

Arifin, Z. (2007). Teori keuangan dan pasar modal. 2nd Edition. Yogyakarta: Ekonisia.

Atmoko, Yudha, Defung, F., dan Tricahyadinata, Irsan., (2017). Pengaruh Return On Assets, Debt To Equity Ratio, dan Firm Size Terhadap Dividend Payout Ratio, Fakultas Ekonomi dan Bisnis Universitas Mulawarman, Samarinda, Volume 14 (2) 2017, 103-109.

Cahyono, D. D., \& Prabawa, S. A. (2011). Pengaruh ukuran Perusahaan, Profitabilitas, Pertumbuhan Asset, Dan Risiko Bisnis Terhadap Struktur Modal Pada Perusahaan Manufaktur Yang Terdaftar di BEI Periode 2008--2012. Jurnal IImiah Manajemen Universitas Bengkulu.

Doğan, M. (2013). Does Firm Size Affect The Firm Profitability? Evidence from Turkey. Research Journal of Finance and Accounting.

Elmagrhi, M. H., Ntim, C. G., Crossley, R. M., Malagila, J. K., Fosu, S., \& Vu, T. V. (2017). Corporate governance and dividend payout policy in UK listed SMEs: The effects of corporate board characteristics. International Journal of Accounting and Information
Management. https://doi.org/10.1108/IJAIM-02-20170020

Eviani, anatia dewi. (2015). pengaruh struktur aktiva, pertumbuhan penjualan, dividend pay out ratio, likuiditas dan profitabilitas terhadap struktur modal. Jurnal Akuntansi Dan Sistem Teknologi Informasi.

https://doi.org/10.1145/3132847.31328 86

Giel, B., Issa, R. R. A., \& Olbina, S. (2019). Return on investment analysis of building information modeling in construction. EG-ICE 2010 - 17th International Workshop on Intelligent Computing in Engineering.

He, W., Ng, L., Zaiats, N., \& Zhang, B. (2017). Dividend policy and earnings management across countries. Journal of Corporate Finance. https://doi.org/10.1016/j.jcorpfin.2016.1 1.014

Henry, T. R., \& Koski, J. L. (2017). Ex-Dividend Profitability and Institutional Trading Skills. Journal of Finance. https://doi.org/10.1111/jofi.12472

Idawati, W., \& Wahyudi, A. (2015). Effect of Earning Per Share (EPS) and Return On Assets (ROA) Against Share Price on Coal Mining Company Listed in Indonesia Stocks Exchange. Journal of Resource Development and Management.

Jiang, F., Ma, Y., \& Shi, B. (2017). Stock liquidity and dividend payouts. Journal of Corporate Finance. https://doi.org/10.1016/j.jcorpfin.2016.1 2.005

Kadir, A. (2010). Analisis Faktor-Faktor Yang Mempengaruhi Kebijakan Dividen Pada Perusahaan Credit Agencies Go Public Di Bursa Efek Indonesia. Jurnal Manajemen Dan Akuntansi.

Kaźmierska-Jóźwiak, B. (2015). Determinants of Dividend Policy: Evidence from Polish Listed Companies. Procedia Economics and Finance. https://doi.org/10.1016/s22125671(15)00490-6

Labhane, N. B., \& Das, R. C. (2015). Determinants of Dividend Payout Ratio: Evidence from Indian Companies. Business and Economic Research. https://doi.org/10.5296/ber.v5i2.8154

Lestari, K. F., Tanuatmodjo, H., \& Mayasari, M. (2017). Pengaruh Likuiditas Dan Profitabilitas Terhadap Kebijakan 
Dividen. Journal of Business Management Education (JBME). https://doi.org/10.17509/jbme.v4i1.2293

Marpaung, E., \& Hadianto, B. (2009). Pengaruh Profitabilitas Dan Kesempatan Investasi Terhadap Kebijakan Dividen: Studi Empirik Pada Emiten Pembentuk Indeks LQ45 Di Bursa Efek Indonesia. Jurnal Akuntansi.

https://doi.org/http://app.maranatha.edu /index.php/jam/article/view/382

Miller, M. H., \& Modigliani, F. (1961). Dividend Policy, Growth, and the Valuation of Shares. The Journal of Business. https://doi.org/10.1086/294442

Mui, Y. T., \& Mustapha, M. (2016). Determinants of Dividend Payout Ratio: Evidence from Malaysian Public Listed Firms. Journal of Applied Environmental and Biological Sciences.

Paminto, A., Setyadi, D., \& Sinaga, J. (2016). The Effect of Capital Structure, Firm Growth and Dividend Policy on Profitability and Firm Value of the Oil Palm Plantation Companies in Indonesia. European Journal of Business and Management.

Rais, B. N., \& Santoso, H. F. (2017). Pengaruh Kepemilikan Manajerial, Kepemilikan Institusional, Profitabilitas dan Ukuran Perusahaan Terhadap Kebijakan Deviden. Jurnal IImiah Manajemen Bisnis, 17(2), 111-124.

Rehman, O. U. (2016). Impact of Capital Structure and Dividend Policy on Firm Value. Journal of Poverty, Investment, and Development.

Roy, A. (2015). Dividend policy, ownership structure, and corporate governance: An empirical analysis of Indian firms. Indian Journal of Corporate Governance, 8(1): 1-33.

Sartono, Agus., (2015), Manajemen Keuangan Teori dan Aplikasi: Edisi keempat, Jogjakarta, BPFF.

Samrotun, Y. (2015). Kebijakan Dividen Dan Faktor-Faktor Yang Mempengaruhinya. Jurnal Paradigma Universitas Islam Batik Surakarta.

Torres-Reyna, O. (2014). Panel Data Analysis Fixed \& Random Effects. Princeton University.

Trang, I., Murni, S., \& Pantow, M. S. (2015). Analisa Pertumbuhan Penjualan, Ukuran Perusahaan, Return On Asset, Dan Struktur Modal Terhadap Nilai Peruahaan Yang Tercatat Di Indeks LQ45. Jurnal Riset Ekonomi, Manajemen, Bisnis Dan Akuntansi. https://doi.org/10.35794/emba.v3i1.780 1.

Wahyuni, Sr F., dan Hafiz, Muhammad S., (2018), Pengaruh CR, DER dan ROA Terhadap DPR Pada Perusahaan Manufaktur di BEI, Jurnal Ekonomi \& Ekonomi Syariah, Volume 1 No. 2, Tahun 2018, E-ISSN :2559-3410 I PISSN: 4321-1234.

Wicaksono, Santiko., dan Nasir, Mohamad., (2014) : Faktor-Faktor yang Mempengaruhi Kebijakan Dividen Pada Perusahaan Manufaktur yang Terdaftar Di BEl Periode Tahun 2011 - 2013, Universitas Diponegoro, Diponegoro Journal Of Accounting, Volume 3, Nomor 4, Tahun 2014, Halaman 1-13, ISSN : 2337-3806.

Wonggo, Fatra., Nangoy, Sientje C., dan Pasuhuk, Altje S., (2016). Analisis Pengaruh Profitabilitas, Leverage dan Harga Saham Terhadap Kebijakan Dividen Tunai (Studi Pada Perusahaan LQ-45 Di Bursa Efek Indonesia Periode 2009 - 2013), Universitas Sam Ratulangi, Volume 16 No. 01 Tahun 2016.

Yusof, Y., \& Ismail, S. (2016). Determinants of dividend policy of public listed companies in Malaysia. Review of International Business and Strategy. https://doi.org/10.1108/RIBS-02-20140030

Zais, Gogor Mustawa., (2017) : Faktor-Faktor yang Mempengaruhi Kebijakan Dividen Pada Perusahaan Industri Barang Konsumsi Di Bursa Efek Indonesia, Universitas Tridinanti Palembang, Jurnal Kompetitif Vol.6 No. 1 Ed. Januari - Juli 2017.

http://www.idx.co.id accessed September 21, 2019

http://www.sahamok.co.id accessed September 21, 2019

http://www.yahoofinance.com September 21, 2019 accessed 